\title{
Guided Inquiry Learning in the Concept of Carbon Compounds to Enhance Students' Science Process Skills
}

\author{
Euis Nursa'adah ${ }^{1, *}$, Sanjaya $^{2}$, Irah Namirah $^{2}$ and Agus Sundaryono ${ }^{1}$ \\ ${ }^{1}$ Graduate School of Science Education, University of Bengkulu, Jln. WR Supratman Kandang Limun, Bengkulu \\ ${ }^{2}$ Department of Chemistry Education, Faculty of Teacher Training and Education, University of Sultan Ageng \\ Tirtayasa. \\ "Corresponding author. Email: euis@unib.ac.id
}

\begin{abstract}
Science process skills are very important for every student as a provision to use the scientific method in developing science. Through a quasi-experimental research method with a non-equivalent control group design, this study aims to implement guided inquiry learning on the concept of carbon compounds to improve students' science process skills. Participants in this study consisted of 30 students in the control class and 30 students in the experimental class. Students' essay tests and worksheets were used to measure their science process skills. Hypothesis testing was carried out using the t-test independent sample t-test. The post-test average score for the experimental class was 73.46 and the control class was 44.7. The results showed that the science process skills of the experimental class differed significantly from the control class $(\alpha=000)$. Designing and planning an experiment was the best skill achieved by students in both the control and experimental classes, while making a hypothesis in the experimental class and asking questions in the control class were the lowest skills achieved by students. Therefore, it can be concluded that guided inquiry learning can develop students' science process skills with the aspect of designing and planning an experiment being the highest aspect.
\end{abstract}

Keywords: Guided-inquiry, Science process skills, Carbon compounds.

\section{INTRODUCTION}

Chemistry is a science consisting of processes and products. Chemistry as a product consists of facts, concepts, principles, laws, and theories which are the findings of scientists. Chemistry as a process is scientific work. The purpose of learning chemistry is to obtain a long-term understanding of various facts, the ability to recognize and solve problems, have the skills to use tools and materials in the laboratory, and be able to be a scientific [1].

The data obtained in the laboratory is very supportive for producing efficient science learning, but often students have difficulty connecting activities in the laboratory with science learning [2]. Other fact shows that in studying science, students tend to memorize concepts, theories, and principles without interpreting the process [3]. As a result, students become less skilled to think and use reason in understanding natural phenomena that occur or when they facing problems.

One of the chemical concepts in Indonesian senior high school is carbon compounds. The concept of carbon compounds can be taught using the mind mapping assignment method in the jigsaw model [4]. Through this model, students write organized concepts. This method can improve their learning outcomes.

Besides, the concept of carbon compounds can be taught using a cooperative learning model to increase student activity and learning outcomes [5]. Based on this opinion, learning carbon compounds is still oriented towards scientific products without looking at the scientific process. In order to get students' better understanding in the concept of learning and the nature 
of science as a process and product, a practicum is needed [6]. Thus, students can understand that chemistry learning is not only product-oriented but also process skills, namely science process skills (SPS).

SPS is process thinking skills using scientific processes understanding, developing, and discovering science [7]. SPS is very important for students as a provision for using the scientific method in developing science, acquiring new knowledge, and developing knowledge they already have.

The advantage of SPS is able to provide scientific stimulation so that students can understand the facts and concepts of science well. Also, it can provide students with opportunities to work with science. Thus, science learning does not only tell or listen to stories about science but also carries out processes related to findings of science itself which make students more active.

The practicum is one of the learning methods that can be used to equip students' SPS. Through practicum, students can develop basic experimental skills. It means achieving a science learning orientation, which is product and process-oriented [8]. A practicum is the best way of developing SPS [9]. Learning with the practicum allows students to experience themselves or do the learning process themselves.

In general, practicum in schools has not provided experiences for students to make hypotheses, test the hypotheses, and analyze data. It caused by practicum procedures used generally contain direct instructions and students only carry out the steps according to orders. As a result, they do not train thinking skills and SPS. In addition, the practicum activities do not provide opportunities for students to actively participate in conducting experiments and to find their own concepts [8].

Based on this explanation, a practicum is needed to develop students' SPS. Inquiry learning design is used to implement SPS in practicum. Through inquiry learning, students are required to ask questions, seek information, and conduct investigations. Joyce (Gulo, 2005) suggests general conditions in inquiry learning are: (1) social aspects in the classroom such as freeopenness and permissiveness that support students to discuss; (2) focuses on hypotheses that need to be verified; and (3) the use of facts as valid and reliable evidence to test the hypothesis.

One of the types of inquiry learning is known as guided inquiry learning. Guided inquiry learning is a learning process to reach the scientific process and able to explore students' critical, logical, and creative thinking skills [10].

Based on this description, the purpose of this research is to implement practicum method base guided inquiry learning to develop students' science process skills on the concept of carbon compounds.

\section{RESEARCH METHOD}

The research was conducted in a senior high school in Serang Regency. The study participants consisted of 30 students in the control class and 30 students in the experimental class. The research design used a nonequivalent control group design. The design consisted of two classes, experimental and control.

The instruments used were essay tests and students' worksheets. The data obtained through tests and worksheets were analyzed and tested for hypotheses using SPSS. Hypothesis testing was used to see the effect of using guided inquiry-based practicum learning on the development of students' scientific processes.

\section{RESULTS AND DICUSSION}

Learning activities in the experimental class were designed based on the characteristics of guided inquirybased learning. In the control class, they used direct instruction.

Students' worksheets in the experimental class required students to formulate problems and hypotheses from the phenomena. In the next step, students must test the hypothesis, design the necessary experiments, classify the observational data, interpret the results of the observations, and make conclusions to enhance students' science process skills.

In the control class, students follow the steps presented on the worksheet without having to formulate problems, make hypotheses, and determine tools also materials, determine experimental steps, interpret, and conclude. They did experiments to prove the theory.

Students' science process skills data both experimental and control are presented in Table 1.

Table 1. Score of Control and Experimental Classes

\begin{tabular}{lcc}
\hline \multirow{2}{*}{ Data } & \multicolumn{2}{c}{ Class } \\
\cline { 2 - 3 } & Control & Experimental \\
\hline $\begin{array}{l}\text { Sum of } \\
\text { student }\end{array}$ & 30 & 30 \\
$\begin{array}{l}\text { Highest } \\
\text { score }\end{array}$ & 64,47 & 89,47 \\
Lowest & 32,89 & 61,84 \\
score & & \\
Mean & 44,7 & 73,46
\end{tabular}

Based on Table 1, the mean score of the experimental class is higher than the control class. This shows that guided inquiry-based practicum learning gives better results in developing students' science process skills. The hypothesis is tested using an 
independent sample test. The result shows the acceptance of $\mathrm{H}_{1}$. The effect size is used to measure the effect of guided inquiry learning on students' science process skills. The Effect Size $(\mu)$ is 0.9 (high category)

The result of the effect size shows that $90 \%$ of guided inquiry-based practicum learning has a 'big' effect on the development of students' science process skills. These results are relevant to Ambarsari, et al. application of guided inquiry learning has a significant effect on students' science process skills [11]. In addition, experiments in guided inquiry-based laboratories provide students conducting experiments, eliminating anxiety while in the laboratory, and having a better impact on student learning outcomes [12].

The results of this study support research findings regarding the application of inquiry learning in science learning which can improve students' understanding of content and context, as well as foster good interactions in the learning process [13], [14], [15], [16], [17], [18], [19].

Students' science process skills in detail can be seen in Figure 1.

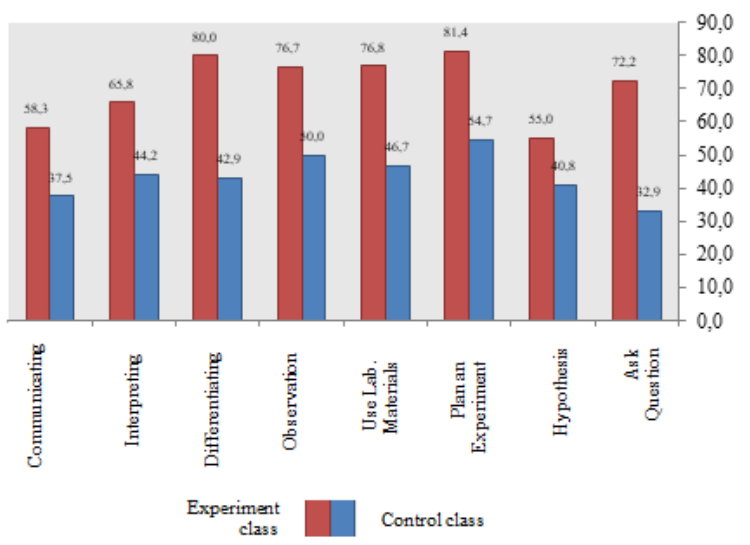

Figure 1. Students' science process skills

Based on Figure 1, the first aspect of the SPS is asking questions. Asking questions includes the ability to ask what, how, and why, asking for explanations, and asking questions related to hypotheses [9]. To measure it, students are given description questions.

In this question, students are given a discourse on the use of alcohol, aldehyde, ketones, carboxylic acids, and esters in daily life. Then students are demanded to ask several questions related to the discourse. The questions that are expected are: 1) how to identify alcohol compounds, aldehydes, ketones, and carboxylic acids? 2) Why can alcoholic compounds of alcohol, aldehyde, ketones, and carboxylic acids be identified, and 3) what are the characteristics of the identified alcohol, aldehyde, ketone, and carboxylic acid compounds.

Based on Figure 1, the mean score of the skill to ask questions in the control class is $32.9 \%$ (less) while in the experimental class is $72.2 \%$ (good). This shows that guided inquiry-based practicum learning on the concept of carbon compounds can develop aspects of student question-asking skills.

Furthermore, in the hypothesis aspect, the mean score of the control class is $41 \%$ (less) while the experimental class is $55 \%$ (less). The hypothesized aspect is developed by making temporary answers to the problems presented in the students' worksheets. The students' skills in hypothesizing are not as expected. One of the factors that caused it is the questions presented do not support students to hypothesize. In the questions that are presented with only one possible answer, the questions made should encourage students to make explanations that have several possible answers. In hypothesizing, there must be several possibilities that explain a fact [9]. In addition, students must be aware that the hypothesis must be tested by presenting evidence.

In the aspect of planning the experiment, the mean score of the control class is $54.7 \%$ (less) while in the experimental class it is $81.4 \%$ (good). In planning the experiment, students must be able to determine the tools and materials used, determine the control and also independent variables, and determine the experimental procedure [9]. Thus, guided inquiry-based practicum learning can develop students' experimental planning skills. Students are allowed to design experiments by group discussions.

In the aspect of using tools and materials, the mean score of the control class students is $46.7 \%$ (less), while in the experimental class is $76.8 \%$ (good). Using tools and materials is very important in chemistry practicum. Through guided inquiry-based practicum learning, students are trained to use tools and materials by themselves so that skills in using tools and materials can be developed properly. Guided inquiry learning provides time for students to gain direct learning experiences.

Furthermore, the observation aspect (observing), the mean score of the control class is $50 \%$ (less) and the experimental class is $76.7 \%$ (good). Observation skills are skills using the senses. Observation skills are developed in the carbon compound identification practicum. Students use the sense of sight to observe color changes in the identification experiment of methanol and ethanol compounds, the presence of deposits in the identification experiment of formaldehyde and acetone compounds, and use the sense of smell in the identification experiment of carboxylic acid compounds.

In the classification aspect, the mean score of the control class is $42.9 \%$ (less) and the experimental class is $80 \%$ (good). Classifying is a process skill for sorting various objects and events based on their specific 
properties. In guided inquiry-based practicum learning, classifying skills are developed by collecting observational data, looking for similarities or differences based on the specific characteristics of carbon compounds.

Interpreting skill is the skill to find patterns in a series of observations and to make a conclusion [9]. This skill is developed through the interpretation of the results of the observations and related to the initial hypothesis. The percentage of the mean score of students' interpreting skills is $65.8 \%$ (sufficient) in the experimental class and $44.2 \%$ (less) in the control. These results indicate the effect of the application of inquiry learning in the experimental class on developing students' interpretation skills.

The last is communication skills. Indicators communicate, including describing images or empirical data and turning them into sentences, diagrams, graphics, and so on [20]. Mean of score in control class is $37.5 \%$ (less) and $58.3 \%$ (less) in the experimental class. The aspect of communication skills is developed by asking students to change their observations data into tables with explanations. The results showed that there were still many students who could not communicate well because of several obstacles, including not being able to describe the data.

\section{CONCLUSION}

Based on the results of research and discussion, it is concluded that the application of guided inquiry-based practicum learning succeeded in developing students' science process skills on the concept of carbon compounds with a size effect of 0.9. The application of guided inquiry-based practicum learning develops students' science process skills with the highest aspect in planning an experiment $81 \%$ (good).

\section{REFERENCES}

[1] Sastrawijaya, T. S. Belajar Mengajar Kimia. Jakarta: Depdikbud Dirjen Dikti Proyek Pengembangan LPTK; 1998.

[2] Hofstein, Avi. The laboratory In chemistry education: thirty years of experience with developments, implementation, and research. Chemistry Education: Research And Practice. 2004; 5(3), 247-264.

[3] Depdiknas. Kurikulum 2004 SMA: Pedoman Khusus Pengembangan Silabus dan Penilaian Mata Pelajaran Kimia. Jakarta: Ditjen Dikdademen Direktorat Dikmenum; 2003.

[4] Abdullah, Y., dkk. Penugasan Mind Mapping (MM) Dalam Pembelajaran Model Jigsaw Mampu Meningkatkan Hasil Belajar Tetapi Belum Mampu Meningkatkan Kemampuan Berpikir Tingkat
Tinggi Siswa. Jurnal Pembelajaran Sains. 2017; Vol. No. 1.

[5] Basri, S., \& Kartikaningsih, R. Penerapan Model Pembelajaran Koopratif Tipe Make a Match Untuk Meningkatkan Aktivitas dan Hasil Belajar Kimia Siswa Pada Materi Pokok Senyawa Turunan Alkana di Kelas XII IPA 5 SMA Negeri 5 Kendari. Jurnal Aplikasi Fisika. 2014; Volume 10 Nomor 2.

[6] Wartono. Strategi Belajar Mengajar Fisika. Malang: Universitas Negeri Malang; 2003.

[7] Rezba R J, Sprague C \& Fiel R Learning and Assessing; Scince Process Skills. Iowa: Kendall/Hunt Publishing Company; 2002.

[8] Siska, M., dkk. Peningkatan Keterampilan Proses Sains Siswa SMA Melalui Pemebelajaran Praktikum Berbasis Inkuiri Pada Materi Laju Reaksi. Jurnal Riset dan Praktik Pendidikan Kimia, 2013; Vol. No. 1.

[9] Rustaman, N. Strategi Belajar Mengajar Biologi. Malang; UM Press; 2005.

[10] Liewellyn D. Teaching High School Science Through Inquiry. USA: Corwin Press; 2005.

[11] Ambarsari, W .et,al. Penerapan Pembelajaran Inkuiri Terbimbing Terhadap Keterampilan Proses Sains Dasar Pada Pelajaran Biologi Siswa Kelas VIII SMP Negeri 7 Surakarta. Jurnal Pendidikan Biologi. 2013; Vol. 5 No. 1, 81-95.

[12] Ural, E. The Effect of Guided-Inquiry Laboratory Experiments on Science Education Students' Chemistry Laboratory Attitudes, Anxiety and Achievement. Journal of Education and Training Studies. 2016; Vol. 4 No. 4.

[13] Trundle.K, C. \& Ronald K. Atwood \& John E. Christopher \& Mesut Sackes. The effect of guided inquiry-based instruction on middle school students' understanding of lunar concepts. Res Sci Educ. 2010; 40:451-478.

[14] Sachiko,Tosa. Comparing u.s. and japanese inquiry-based science practices in middle sch ools middle grades. Research Journal, 6(1), 2011, 29 46.

[15] Dias, Michael, Charles J. Eick, and Laurie Brantley-Dias. Practicing what we teach: a selfstudy in implementing an inquiry-based curriculum in a middle grades classroom. J Sci Teacher Educ. 2011; 22:53-78.

[16] Catherine, Bowman, D. D. Student use of animated pedagogical agents in a middle school science inquiry program.British Journal of Educational Technology, 2012; 43 (3), 359-375. 
[17] Rinke,C, R. \& Steven J. Gimbel \& Sophie Haskell. Opportunities for inquiry science in montessori classrooms: learning from a culture of interest, communication, and explanation. Res Sci Educ. 2013; 43:1517-1533.

[18] Olde, Vreman-de, G.C., de Jong, T., Gijlers, H.Learning by designing instruction in the context of simulation-based inquiry learning.Educational Technology \& Society, 2013; 16 (4), 47-58.
[19] MaxwelL,D, O, Dawn T Lambeth, and JT Cox. Effects of using inquiry-based learning on science achievement for fifth-grade students.Asia-Pacific Forum on Science Learning and Teaching, 2015; Volume 16, Issue 1, Article 2, 1-31.

[20]Tawil, M., \& Lilisari. Keterampilan-Keterampilan Sains dan Implementasinya dalam Pembelejaran IPA. Makasar: Badan Penerbit UNM; 2014. 